\title{
Clastogenic and Mutagenic Effect Induced by Some Fast Foods
}

\author{
Amira M. Khatab \\ Institute of Graduate Studies and Research, Alexandria University, Egypt \\ And Faculty of Education, Majmaah University, Kngdom of Saudi Arabia
}

\begin{abstract}
The present work aims at disclosing the capability of some fast foods in inducing clastogenic effect assessed by analysis of chromosomes of Allium cepa and Vicia faba genome, and mutagenic effect assessed by in vivo induction of sister chromatid exchanges in mice genome. To achieve such a purpose Corn chips; Potato chips Burger and mice were locally purshased and used. The present investigation showed that the tested fast foods were proven to be clastogenic agents, since they were capable to interfere with spindle fibers, and C-metaphases were observed, giving a strong evidence that the water-soluble fraction of potato and corn chips as well as of Burger contained contaminants capable to interact with chromosomes arid spindle fibers as well. However they have mutagenic activity as sister chromatid exchanges revealed obtained since positive frequencies of SCEs were observed.
\end{abstract}

Keywords: Clastogene, Mutagen, Fast foods, Mice, Allium cepa and vicia faba.

\section{INTRODUCTION}

Genotoxic compounds in the diet represent a truly international problem. This problem was recognized in Japan and the United States of America several years ago by the application of in vitro mutagenicity tests to prepared and unprepared components of our diet. Now new discoveries are appearing every day concerning genotoxic compounds in our food supply from all over the world. It seems likely that naturally occurring genotoxic compounds in the diet as well as genotoxic compounds formed during storage, preparation, and digestion of the food are important for the induction of cancer in humans and of hereditary changes in human germ cells. Other scientific data indicate that dietary constituents have the potential to modify the genotoxic effect of these compounds in humans. These findings indicate new possibilities for the prevention of human diseases of genotoxic origin through relevant changes in the composition of the diet. (Amara et al.,2008).

With this background, and due to the rapid accumulation of new data in the field, it was approved by the Board of the International Association of Environmental Mutagen Societies that one of the satellite meetings of the Fourth International Conference on Environmental Mutagens in Scandinavia 1985 should cover the aspects of mutagens and carcinogens in the diet. However, formation of polycyclic aromatic hydrocarbons (PAH) occurs during incomplete combustion of organic material. Although the mechanism of this formation is not fully understood, two principal pathways are considered to be involved, pyrolysis and pyrosynthesis. At high temperatures organic compounds are initially cracked to smaller molecules, mostly free radicals, which may then recombine to form a number of relatively stable polycyclic hydrocarbon. Hypothetical schemes for the generation of specific $\mathrm{PAH}$ compounds, such as benzo [a] pyrene $(\mathrm{BaP})$, have been suggested (Knudsen, 1986).

$\mathrm{PAH}$ are formed in the combustion processes used in the production of curing smoke and for the generation of heat during grilling. The combustion fumes may contain both vapour phase and particle- bound PAH. Contaminants of food during grilling and smoking occurs when the combustion fumes reach the surface of the 
food. However, since PAH represent an important group of chemical carcinogens, their presence in food and the environment has been studied intensively during the last two decades. Among the various foods studied for $\mathrm{PAH}$, smoked products seem to have the been most popular. Based on epidemiological studies in several countries, a possible connection between an increased incidence of gastric cancer and a high consumption of smoked food, has been suggested (Knudsen, 1986).

In fact, there are two cytogenetic tests in plants that can be performed in Allium cepa and Vicia faba i.e., the root-tip mitotic and PMC meiotic systems. The former is more widely used and better validated than the latter, especially when chromatid aberrations are used as the indicators of mutagenicity. However, this plant cytogenetic test system is efficient in the preliminary screening of chemical mutagens. Badr et al., (1983), Amara et al., (2008), Badr (1993). It is simple and economical test, and the results can be obtained in $48 \mathrm{hrs}$. Comparative studies of a given chemical under Allium; Vicia., and mammalian system (such as human lymphocytes or mice) are strongly encouraged in order to establish the correlation between the chromosome breaking ability of chemicals in plant and animal system. (Al-Ayoubi (1998) and Albertini et al., (2001).

\section{MATERIALS AND MRTHODS MATERIALS:}

Allium cepa bulbs and Vicia faba were used in this work to assess the possible activity clastogenic, while mice were used to investigate the mutagenic activity by employing in vivo induction of sister chromatide exchange SCE technique.

\section{METHODS :}

\section{Preparation of food materials :}

From each type of fast foods six concentrations were freshly prepared. These concentrations were 10, 20, 30, 40, 50 and 100g per litre. Each concentration was prepared as follows :

The proper amount was grinded well in a morter and mixed with one litre of tap water; shaked overnight on a shaker, centrfigued at 2000 r.p.m. for 15 min., and filtered. The supernatant was saved and immediately used.

Germination of plants :

\section{Allium cepa}

Bulbs were allowed to geminate at $25^{\circ} \mathrm{C}$ using special Jars on tap water until a length of $0.5 \mathrm{~cm}$ for adventitious roots had reached, then they were subjected to treatment by transferring them on Jars containing the previously mentioned supernatant for different times of exposures, i.e., 6, 12 and $24 \mathrm{hrs}$. Mitotic index (MI) was calculated according to the following formula:

$$
\mathrm{MI}=\frac{\text { No. divided cells }}{\text { Total examined cells }} \times 100
$$

\section{Vicia faba}

Vicia faba seeds were soaked in running tap water for 24 hours, transferred to petri dishes on moistened filter paper and allowed to germinate in dark at $25^{\circ} \mathrm{C}$. The filter paper inside each dish was moistened with tap 
water every day. When the primary root reached about $2 \mathrm{~cm}$, the apical meristem was cut in order to stimulate the growing of secondary roots. When secondary roots on each primary one reached about $1 \mathrm{~cm}$ in length, seedling were then transferred in petri dishes and predetermined concentration was added. Six concentrations were used. Secondary roots were treated with the proper concentration for 6,12 and 24 hours, while the control group was on tap water only. After treatment; root-tips of secondary roots and of Allium cepa adventitious roots were cut and transferred to cold glacial acetic acid for one hour and transferred to a fixative solution (Carnoy's solution), and the well known acetocarmine technique (Darlington and La Cour, 1962) was used to examine the mitotic activity. The frequency of mitotic activity (mitotic index) was calculated as the ratio of the total number of normal dividing cells to the total number of examined cells. The frequency of each type of mitotic aberrations was calculated as the ratio of cells containing this type of aberration to the total number of dividing cells.

\section{Sister chromatid exchange technique: Experimental design}

Typically 2-3 month old Swiss albino mice (Mus musculus, $2 \mathrm{n}=40$ ) were locally purchased from the high Institute of Graduate Studies and Research. Four animals per dose were used and analysis of at least 25 cells per animal was carried out. Four selected doses $(10,20,30$ and $40 \mathrm{~g} / \mathrm{L})$ of the tested food were tested.

\section{Bromodeoxyuridine tablet preparation}

Bromodeoxyuridine tablets were prepared as described Seehy et al., (1983) as follows:

Bromodeoxyuridine tablets were prepared by using pellet press (Parr instrument co. Moline, III., USA), equipped with a 0.178 in diameter punch and die. Approximately, $55 \mathrm{mg}$ of pure Bromodeoxyuridine powder were weight, placed in the die, and pressed. In order to maintain consistent compaction hardness (and thus the dissolution rate) among tablets, utilization of the same personal and die adjustment when pressing the powder was conducted. BrdU tablets were protected from light and stored in a freezer until usage.

\section{Bromodeoxyuridine treatment}

The mice were lightly anesthetized by placing it in a closed container with ether until immobile (about $2 \mathrm{~min}$ ). After removal from the container, each mouse was restrained on its back. A small vial of anesthesia was placed near its nose for use in prolonging the inactive state. The lower lateral region was swabbed with alcohol in order to mat the fur down. Clean scissor or a scalpel was used to make a small (approx. $1 \mathrm{~cm}$ ) subcutaneous incision. In order to spread open a deeper subcutaneous pocket, forceps were used, and the tablet was inserted. The wound was then closed with $2-3$ outclip sutures taking full care not to break the tablet, and the animal was returned to its cage. Each animal had received $2 \mathrm{ml}$ of the extract $8 \mathrm{hr}$ after BrdU treatment. All animals were injected intravenously with $20 \mu \mathrm{g}$ colcemid $(1 \mathrm{~mL} / \mathrm{mouse}$, in tail vain) at hr 19- (following BrdU treatment). Control marrow cells harvested $2 \mathrm{hr}$ later revealed a high fraction of metaphases of optimal sister chromatid 
differentiation after staining. It was necessary to delay colocmid and harvest steps for up to several hours when high concentrations were discovered to slow cell cycling and resulted in poor sister chromatid differential staining. Preparation and implantation of BrdU tablets are given in Figures (1a\&b).

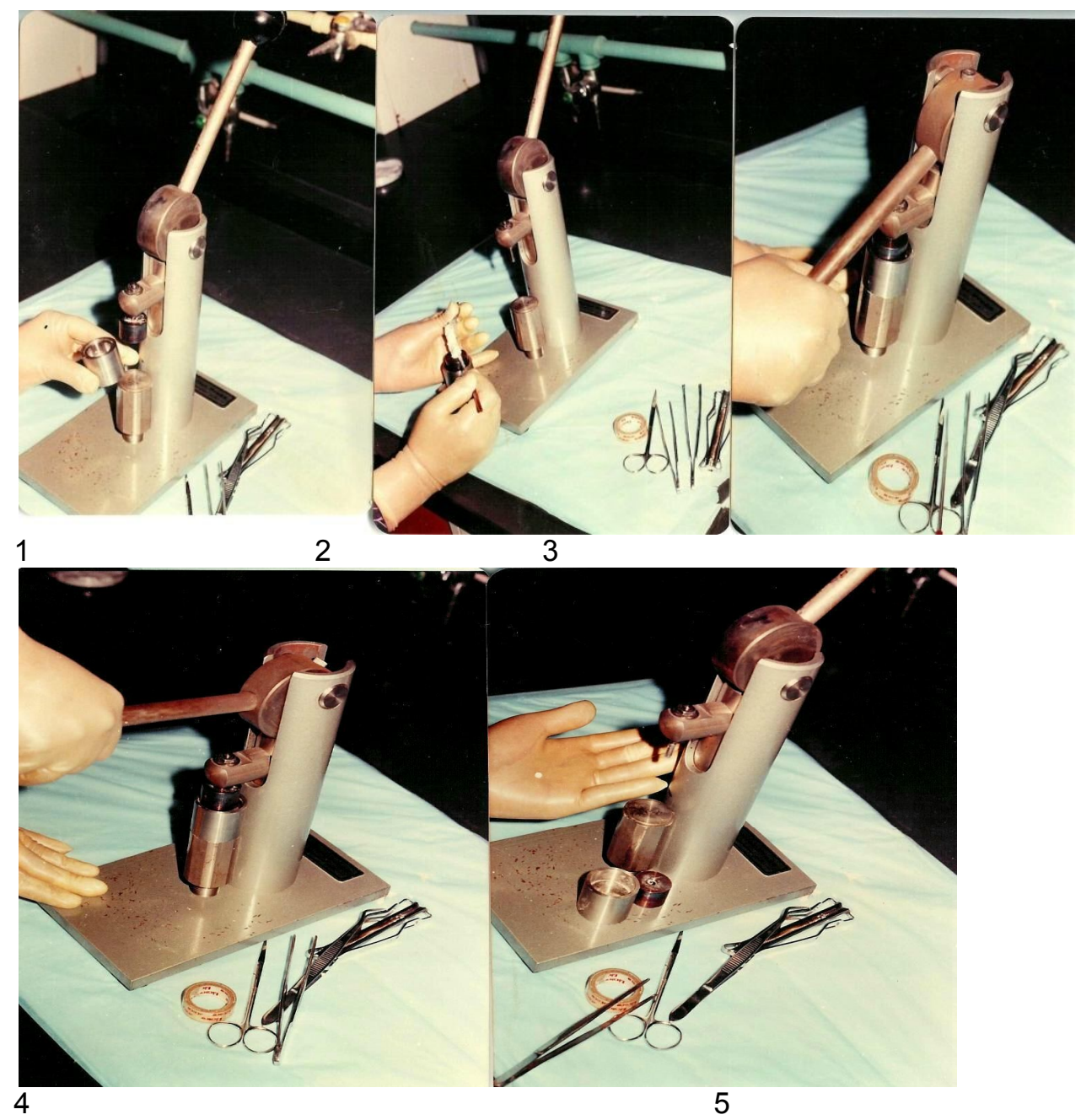

Figure (1a): Preparation of Brdu tablets.
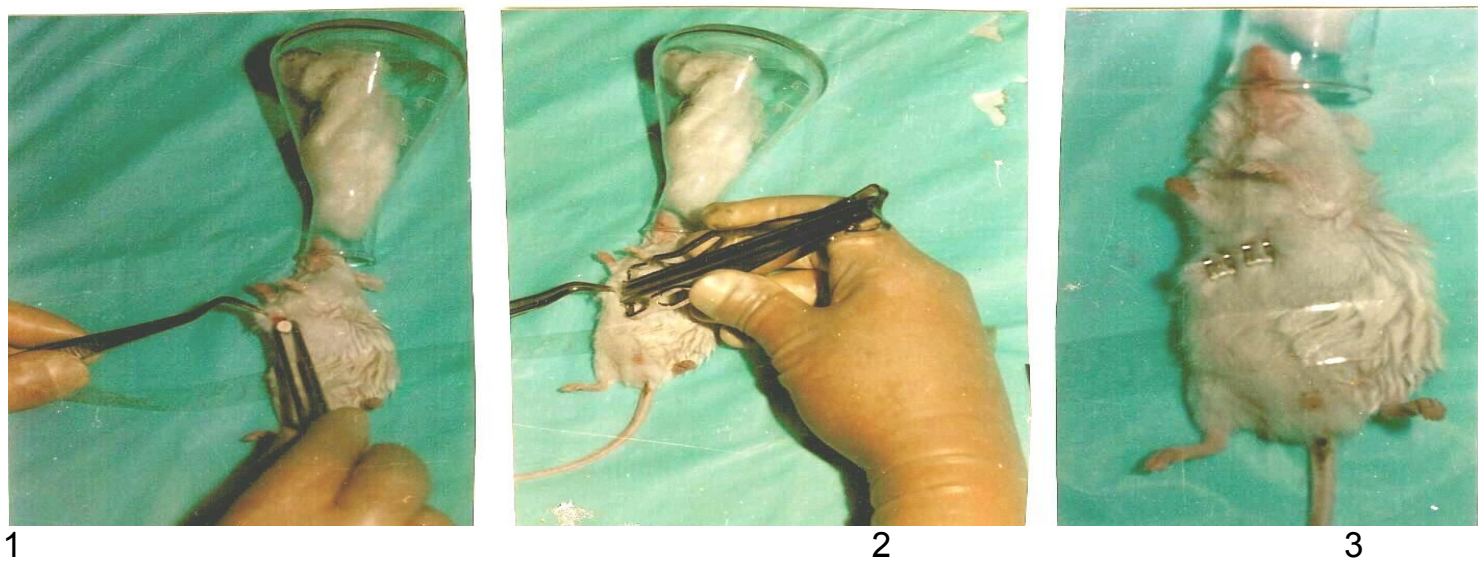

Figure (1b): Implantation of Bromodeoxyuridine (BrdU) tablets. 
Marrow cells harvest, slide preparation and staining:

The procedure that described by Perry \& Evans (1975) and Seehy et al., (1983) was used.

Screening of slides and analysis

Scanning slides for mitotic spreads was conveniently accomplished with a $25 \mathrm{X}$ magnification objective, and analysis was with a 100X objective. For control of bias, all prepared slides were coded prior to scoring. There are three ways for counting sister chromatid exchange frequencies i.e., (1) from the microscope images of second division cells, (2) the cells may be photographed and SCE frequencies counted from the microscope images. An interstitial exchanged segment was counted to be two SCEs.(Seehy et al., 1983).

\section{RESULTS}

\section{Mitotic activity}

Tables (1-19) illustrate the effect of Potato and Corn chips and of Burger water extract upon cellular activity. The results showed that the water- soluble fraction of these foods displayed cellular toxicity upon Allium cepa and Vicia faba cells as well.

In Allium cepa, mitotic activity ranged from $12.9 \%$ to $16.21 \%$ in the control group. It decreased to be 4.6, 3.2 and $1 \%$ for Potato chips at the heighst tested concentration for different times of treatment.

Table (8) shows that, at the heighst tested concentration of Burger $(100 \mathrm{~g} / \mathrm{L})$, no divided cells were obtained, giving an evidence for complete cellular toxicity after $12 \mathrm{hrs}$ treatment time. After $24 \mathrm{hrs}$ treatment time no divided cells (Table,9) at the level of 50 and $100 \mathrm{~g} / \mathrm{L}$ were observed. Table (18) shows the effect of Burger upon Vicia faba cells. At the level of 40; 50; and $100 \mathrm{~g} / \mathrm{L}$, no divided cells were observed, reflecting cellular toxicity of water soluble fraction of Burger.

The present study showed that all tested water extract foods were effective in causing significant decreases in cell proliferation in Allium cepa root cells and Vicia faba as well.(Amara et al., 2008).

\section{Chromosomal aberrations :}

Fragments, ring chromosomes; stickiness; gaps; and C- Metaphases were observed. They increased with the increasing of the tested concentration as well as with the treatment time that ranged from 6 to $24 \mathrm{hrs}$. For example, aberrant metaphase in Allium cepa (Table, 19) were $2 \%$ for the control group. They ranged from 4.2 to $15.4 \%$ after 6 hrs treatment time, and from 2.3 to 21.50 after $12 \mathrm{hrs}$ treatment time (Table, 20), giving a strong evidence that water-soluble fraction of potato chips was shown to be a positive clastogen. Figures (1-10) illustrate the positive effect of the tested foods upon Allium cepa and Vicia faba genome.

Cytological examination revealed that the percent of total aberrant metaphases after treatment with the extraction of fast foods for $24 \mathrm{hrs}$. by $20 \mathrm{gr} / \mathrm{L}$ is given in table 19. Percent of total aberrant metaphases in the control 
group was found to be $2 \%$ and it decreased to be 18.4 after treatment with corn chips and 22.7 after treatment with potato chips. High percentage of stickiness was observed after treatment with Burger extract $(10 \%)$. Percent of total aberrant metaphases was found to be $31 \%$ (15 foldes compared that of the with, the negative control).

This result, however, presented a strong evidence that the tested fast foods have cellular toxicity and clastogenic effect. (This is in agreement with that reported by Erikson (1981).

Stickiness observed in this work might be resulted from an alteration of the net charge of chromosomal proteins and DNA or both (Seehy et al., 2013).

The present work showed that these fast foods are positive clastogens such a conclusion is in agreement with that reported by El-Sebeay (1999).

As shown in Table (21) sister chromatid exchanges were detected and statistically analyzed. Data showed that only one dose $(10 \mathrm{~g} / \mathrm{L})$ from the three tested extract of fast foods was negative, while three doses i.e., 20,30, and $40 \mathrm{~g} / \mathrm{L}$ were proven to be positive, giving an evidence that these fast foods are capable in cousing primary DNA damage or mutagenic effect.

Table (1): Mitotic and phase indices in Allium cepa root cells after treatment with potato chips extract for $6 \mathrm{hrs}$.

\begin{tabular}{lccccc}
\hline $\mathrm{g} / \mathrm{L}$ & ${ }^{*} \mathrm{Ml}$ & Prophase & Metaphase & Anaphase & Telophase \\
\hline Control & 13.84 & 4.20 & 5.01 & 3.10 & 1.53 \\
10 & 11.42 & 6.00 & 2.02 & 2.30 & 1.10 \\
20 & 10.66 & 6.20 & 2.01 & 1.8 & 0.61 \\
30 & 10.14 & 7.02 & 1.86 & 1.06 & 0.20 \\
40 & 10 & 7.12 & 1.82 & 1.02 & 0.04 \\
50 & 8.29 & 7.24 & 0.23 & 0.41 & 0.42 \\
100 & 3.6 & 3 & - & - & 0.6 \\
\hline
\end{tabular}

${ }^{*}$ Mitotic index.

Table (2): Mitotic index and phase indices in Allium cepa root cells after treatment with potato chips for $12 \mathrm{hrs}$.

\begin{tabular}{lccccc}
\hline $\mathrm{g} / \mathrm{L}$ & $\mathrm{Ml}$ & Prophase & Metaphase & Anaphase & Telophase \\
\hline Control & 15.21 & 5.01 & 6.00 & 3.00 & 1.20 \\
10 & 10.14 & 7 & 2.14 & 1 & 0.50 \\
20 & 10.8 & 7 & 1 & 1 & 1.8 \\
30 & 9.01 & 8 & 1 & 0.01 & - \\
40 & 8.02 & 7 & 1.02 & - & - \\
50 & 7.4 & 6.8 & 0.4 & 0.2 & - \\
100 & 2.2 & 2.1 & - & - & 0.1 \\
\hline
\end{tabular}


Table (3): Mitotic index and phase indices in Allium cepa root cells after treatment with potato chips for $24 \mathrm{hrs}$.

\begin{tabular}{lccccc}
\hline g/L & Ml & Prophase & Metaphase & Anaphase & Telophase \\
\hline Control & 11.9 & 5.2 & 4.1 & 1.4 & 1.2 \\
10 & 9.2 & 6 & 1.2 & 1.4 & 0.6 \\
20 & 7.62 & 6.20 & 1.00 & 0.40 & 0.02 \\
30 & 5 & 4.1 & 0.4 & 0.2 & 0.3 \\
40 & 3 & 2.2 & 0.2 & - & 0.6 \\
50 & 1 & 1.00 & - & - & - \\
100 & 0 & 0 & - & - & - \\
\hline
\end{tabular}

Table (4): Mitotic index and phase indices in Allium cepa root cells after treatment with corn chips for 6 hrs.

\begin{tabular}{lccccc}
\hline $\mathrm{g} / \mathrm{L}$ & $\mathrm{Ml}$ & Prophase & Metaphase & Anaphase & Telophase \\
\hline Control & 14.84 & 4.20 & 5.01 & 3.10 & 2.53 \\
10 & 14.02 & 4.12 & 4.20 & 2 & 3.70 \\
20 & 13.10 & 4.01 & 3.88 & 3.21 & 2 \\
30 & 12.00 & 5.20 & 2.00 & 2.5 & 2.3 \\
40 & 11.08 & 6.20 & 1.7 & 2.12 & 1.06 \\
50 & 10.42 & 6.50 & 0.80 & 1.04 & 2.08 \\
100 & 4.11 & 4.00 & - & - & 0.11 \\
\hline
\end{tabular}

Table (5): Mitotic index and phase indices in Allium cepa root cells after treatment with corn chips for 12 hrs.

\begin{tabular}{lccccc}
\hline $\mathrm{g} / \mathrm{L}$ & $\mathrm{Ml}$ & Prophase & Metaphase & Anaphase & Telophase \\
\hline Control & 15.21 & 5.01 & 6.00 & 3.00 & 1.20 \\
10 & 11.1 & 6 & 3 & 1 & 1.1 \\
20 & 9.1 & 6 & 2.1 & 0.2 & 0.8 \\
30 & 8.2 & 6 & 1.2 & 0.6 & 0.4 \\
40 & 5.2 & 4.2 & - & - & 1 \\
50 & 4.3 & 3.3 & - & - & 1 \\
100 & 1.1 & 1.1 & - & - & - \\
\hline
\end{tabular}

Table (6): Mitotic index and phase indices in Allium cepa root cells after treatment with corn chips for 24 hrs.

\begin{tabular}{lccccc}
\hline $\mathrm{g} / \mathrm{L}$ & $\mathrm{Ml}$ & Prophase & Metaphase & Anaphase & Telophase \\
\hline Control & 11.9 & 5.2 & 4.1 & 1.4 & 1.2 \\
10 & 10.3 & 4 & 3 & 2 & 1.3 \\
20 & 8.4 & 4 & 1.4 & 2 & 1 \\
30 & 6.2 & 4.2 & 1 & 1 & - \\
40 & 3 & 1 & 1 & 0.6 & 0.4 \\
50 & 1 & 0.8 & - & - & 0.2 \\
100 & 0.2 & 0.2 & - & - & - \\
\hline
\end{tabular}


Table (7): Mitotic index and phase indices in Allium cepa root cells after treatment with Burger for 6 hrs.

\begin{tabular}{lccccc}
\hline $\mathrm{g} / \mathrm{L}$ & $\mathrm{Ml}$ & Prophase & Metaphase & Anaphase & Telophase \\
\hline Control & 13.84 & 4.20 & 5.01 & 3.10 & 1.53 \\
10 & 12.20 & 5.1 & 4.1 & 2 & 1 \\
20 & 11.50 & 4.60 & 3.20 & 2.00 & 1.50 \\
30 & 10.00 & 4.80 & 2.20 & 1.2 & 1.8 \\
40 & 8.2 & 5.2 & 1.2 & 0.6 & 40 \\
50 & 7.2 & 5.4 & - & 1.2 & 50 \\
100 & 5 & 5.00 & - & - & - \\
\hline
\end{tabular}

Table (8): Mitotic index and phase indices in Allium cepa root cells after treatment with Burger for 12 hrs.

\begin{tabular}{lccccc}
\hline $\mathrm{g} / \mathrm{L}$ & $\mathrm{Ml}$ & Prophase & Metaphase & Anaphase & Telophase \\
\hline Control & 15.21 & 5.01 & 6.00 & 3.00 & 1.20 \\
10 & 8.4 & 5.6 & 1.4 & 0.60 & 0.44 \\
20 & 7.04 & 4.8 & 1.2 & 0.24 & 0.8 \\
30 & 5.21 & 2 & 1.2 & 1.01 & 1 \\
40 & 3.1 & 1.1 & - & 1 & 1 \\
50 & 1.1 & 1.1 & - & - & - \\
100 & - & - & - & - & - \\
\hline
\end{tabular}

Table (9): Mitotic index and phase indices in Allium cepa root cells after treatment with Burger for $24 \mathrm{hrs}$.

\begin{tabular}{lccccc}
\hline g/L & Ml & Prophase & Metaphase & Anaphase & Telophase \\
\hline Control & 11.9 & 5.2 & 1 & 1.4 & 1.2 \\
10 & 5.04 & 3.2 & - & 1 & 0.84 \\
20 & 4.36 & 2.8 & - & 0.23 & 1.30 \\
30 & 3.12 & 2.17 & - & 0.66 & 0.29 \\
40 & 1.01 & 1.01 & - & - & - \\
50 & - & - & - & - & - \\
100 & - & - & - & - & - \\
\hline
\end{tabular}

Table (10): Mitotic and phase indices in Vicia faba root cells after treatment with potato chips extract for 6 hrs.

\begin{tabular}{lccccc}
\hline $\mathrm{g} / \mathrm{L}$ & $\mathrm{Ml}$ & Prophase & Metaphase & Anaphase & Telophase \\
\hline Control & 8.12 & 1.00 & 4.52 & 1.20 & 1.40 \\
10 & 7.01 & 2.00 & 3.00 & 1.00 & 1.01 \\
20 & 6.92 & 2.10 & 2.02 & 1 & 1.80 \\
30 & 5.22 & 3 & 1 & 0.4 & 0.82 \\
40 & 3.28 & 3 & - & - & 0.28 \\
50 & 1.11 & 1 & - & - & 0.11 \\
100 & - & - & - & - & - \\
\hline
\end{tabular}


Table (11): Mitotic and phase indices in Vicia faba root cells after treatment with potato chips extract for $12 \mathrm{hrs}$.

\begin{tabular}{lccccc}
\hline g/L & Ml & Prophase & Metaphase & Anaphase & Telophase \\
\hline Control & 10.20 & 2.6 & 5.2 & 1.4 & 1.00 \\
10 & 6.60 & 2 & 2.2 & 1.3 & 1.1 \\
20 & 6.2 & 3 & 1.2 & 1 & 1 \\
30 & 5.3 & 3.4 & 0.6 & - & 1.3 \\
40 & 2 & 2 & - & - & - \\
50 & 0.02 & 0.02 & - & - & - \\
100 & - & - & - & - & - \\
\hline
\end{tabular}

Table (12): Mitotic and phase indices in Vicia faba root cells after treatment with potato chips extract for $24 \mathrm{hrs}$.

\begin{tabular}{lccccc}
\hline $\mathrm{g} / \mathrm{L}$ & $\mathrm{Ml}$ & Prophase & Metaphase & Anaphase & Telophase \\
\hline Control & 8.03 & 1.00 & 5.00 & 1.00 & 1.03 \\
10 & 3.04 & 1 & 1 & 0.04 & 1.00 \\
20 & 2.06 & 1 & 1 & 0.06 & - \\
30 & 2.01 & 1.4 & - & 0.01 & 0.60 \\
40 & 1.20 & 1.20 & - & - & - \\
50 & - & - & - & - & - \\
100 & - & - & - & - & - \\
\hline
\end{tabular}

Table (13): Mitotic and phase indices in Vicia faba root cells after treatment with Corn chips extract for 6 hrs.

\begin{tabular}{lccccc}
\hline $\mathrm{g} / \mathrm{L}$ & $\mathrm{Ml}$ & Prophase & Metaphase & Anaphase & Telophase \\
\hline Control & 8.12 & 1.00 & 4.52 & 1.20 & 1.40 \\
10 & 8.4 & 2 & 3.5 & 2.4 & 0.5 \\
20 & 6.8 & 2 & 2 & 1.2 & 1.6 \\
30 & 6.61 & 3.1 & 1.2 & 1.01 & 1.3 \\
40 & 5.8 & 3.8 & 1 & 0.8 & 0.2 \\
50 & 2.0 & 2.00 & - & - & - \\
100 & 1.0 & 1.00 & - & - & - \\
\hline
\end{tabular}

Table (14): Mitotic and phase indices in Vicia faba root cells after treatment with Corn chips extract for $12 \mathrm{hrs}$.

\begin{tabular}{lccccc}
\hline g/L & Ml & Prophase & Metaphase & Anaphase & Telophase \\
\hline Control & 10.2 & 2.60 & 5.20 & 1.4 & 1.00 \\
10 & 7.6 & 3.00 & 2.00 & 1.20 & 1.40 \\
20 & 5.90 & 3.00 & 1 & 0.80 & 1.10 \\
30 & 5.20 & 3.20 & 0.80 & - & 1.20 \\
40 & 4.80 & 3.60 & 0.40 & - & 0.80 \\
50 & 2 & 1.8 & - & - & 0.20 \\
100 & 0 & 0 & - & - & - \\
\hline
\end{tabular}


Table (15): Mitotic and phase indices in Vicia faba root cells after treatment with Corn chips extract for $24 \mathrm{hrs}$.

\begin{tabular}{lccccc}
\hline g/L & Ml & Prophase & Metaphase & Anaphase & Telophase \\
\hline Control & 8.03 & 1.00 & 5.00 & 1.00 & 1.03 \\
10 & 5.06 & 3.20 & 1.00 & 0.60 & 0.80 \\
20 & 3.70 & 2.01 & 0.80 & 0.19 & 0.70 \\
30 & 3.16 & 2.00 & 0.60 & 0.22 & 0.34 \\
40 & 2.01 & 2.01 & - & - & - \\
50 & 0 & 0 & - & - & - \\
100 & - & - & - & - & - \\
\hline
\end{tabular}

Table (16): Mitotic and phase indices in Vicia faba root cells after treatment with Burger extract for $6 \mathrm{hrs}$.

\begin{tabular}{lccccc}
\hline $\mathrm{g} / \mathrm{L}$ & $\mathrm{Ml}$ & Prophase & Metaphase & Anaphase & Telophase \\
\hline Control & 8.12 & 1.00 & 4.52 & 1.20 & 1.40 \\
10 & 8.01 & 2.00 & 3.00 & 2.00 & 1.01 \\
20 & 7.70 & 3.00 & 2.00 & 1.60 & 1.10 \\
30 & 7.84 & 3.02 & 1.80 & 1.00 & 2.02 \\
40 & 6.82 & 4.03 & 1.06 & 0.62 & 1.11 \\
50 & 5.82 & 4.00 & 0.66 & 1.00 & 0.16 \\
100 & 3 & 3 & - & - & - \\
\hline
\end{tabular}

Table (17): Mitotic and phase indices in Vicia faba root cells after treatment with Burger extract for $12 \mathrm{hrs}$.

\begin{tabular}{lccccc}
\hline $\mathrm{g} / \mathrm{L}$ & $\mathrm{Ml}$ & Prophase & Metaphase & Anaphase & Telophase \\
\hline Control & 10.2 & 1.60 & 5.20 & 1.4 & 2.00 \\
10 & 6.17 & 1.01 & 3.02 & 1.04 & 1.10 \\
20 & 6.08 & 1.80 & 2.00 & 1.06 & 1.22 \\
30 & 5.92 & 1.89 & 1.88 & 1.02 & 1.13 \\
40 & 2.22 & 1.21 & 1.01 & - & - \\
50 & 1.00 & 1.00 & - & - & - \\
100 & - & - & - & - & - \\
\hline
\end{tabular}

Table (18): Mitotic and phase indices in Vicia faba root cells after treatment with Burger extract for $24 \mathrm{hrs}$.

\begin{tabular}{lccccc}
\hline $\mathrm{g} / \mathrm{L}$ & $\mathrm{Ml}$ & Prophase & Metaphase & Anaphase & Telophase \\
\hline Control & 8.03 & 1.00 & 5.00 & 1.00 & 1.03 \\
10 & 2.16 & 1.10 & 0.40 & - & 0.66 \\
20 & 2.09 & 1.00 & 0.32 & 0.01 & 0.76 \\
30 & 1.17 & 1.17 & - & - & - \\
40 & - & - & - & - & - \\
50 & - & - & - & - & - \\
100 & - & - & - & - & - \\
\hline
\end{tabular}


Table (19): Chromosomal aberrations induced after treatment of Allium cepa roots extraction with fast foods ${ }^{*}$ for $24 \mathrm{hrs}$.

\begin{tabular}{lcccccc}
\hline Types & Fragment & $\begin{array}{c}\text { Ring } \\
\text { chromosome }\end{array}$ & Stickiness & Gap & C-metaphase & $\begin{array}{c}\text { Percent of } \\
\text { total } \\
\text { aberrant } \\
\text { metaphases }\end{array}$ \\
\hline $\begin{array}{l}\text { Control } \\
\begin{array}{l}\text { Potato } \\
\text { chips }\end{array}\end{array}$ & - & - & 2 & - & - & $2 \%$ \\
$\begin{array}{l}\text { Corn } \\
\text { chips }\end{array}$ & 3.4 & 6.5 & 8 & - & 2 & 22.7 \\
Burger & 8 & 8 & 6 & 1 & 2 & 18.4 \\
\hline$* 20 \mathrm{~g} / \mathrm{L}$ & & & 10 & 2 & 3 & 31 \\
\hline
\end{tabular}

Table (20): Chromosomal aberrations induced after treatment of Vicia faba roots with fast food extraction for $24 \mathrm{hrs}$.

\begin{tabular}{|c|c|c|c|c|c|c|}
\hline Types & Fragment & $\begin{array}{c}\text { Ring } \\
\text { chromosome }\end{array}$ & Stickiness & Gap & $\begin{array}{c}\text { C- } \\
\text { metaphase }\end{array}$ & $\begin{array}{c}\text { Percent of } \\
\text { total } \\
\text { aberrant } \\
\text { metaphases }\end{array}$ \\
\hline Control & - & - & 2 & - & - & 2 \\
\hline $\begin{array}{l}\text { Potato } \\
\text { chips }\end{array}$ & 8 & 7 & 4 & 4 & 2 & 25 \\
\hline $\begin{array}{l}\text { Corn } \\
\text { chips }\end{array}$ & 5.5 & 9.5 & 6 & 4 & 2 & 26 \\
\hline Burger & 11 & 12 & 13 & 2 & 4 & 32 \\
\hline
\end{tabular}

Table (21): Averages \pm S.E of sister chromatid exchanges in mice bone marrow cells after oral treatment with the extract of the tested fast foods.

\begin{tabular}{llll}
\hline Dose; $\mathrm{g} / \mathrm{L}$ & & $\mathrm{X} \pm \mathrm{SE}$ & Range \\
\hline Control & & $2.1 \pm 0.1$ & $1-3$ \\
Potato chips & 10 & $2.2^{*}$ & $1-4$ \\
& 20 & $3.4^{*}$ & $2-5$ \\
& 30 & $5.2^{*}$ & $3-6$ \\
Corn chips & 40 & $8.4^{*}$ & $4-10$ \\
& 10 & 2.1 & $1-4$ \\
& 20 & $4.2^{*}$ & $2-6$ \\
Burger & 30 & $4.6^{*}$ & $2-8$ \\
& 40 & $10.2^{*}$ & $4-12$ \\
& 10 & 2.4 & $2-4$ \\
& 20 & $4.2^{*}$ & $3-6$ \\
& 30 & $6.2^{*}$ & $4-8$ \\
& 40 & $12.4^{*}$ & $7-14$ \\
\hline
\end{tabular}

${ }^{*}$ Significant at 0.05 level of probability. 

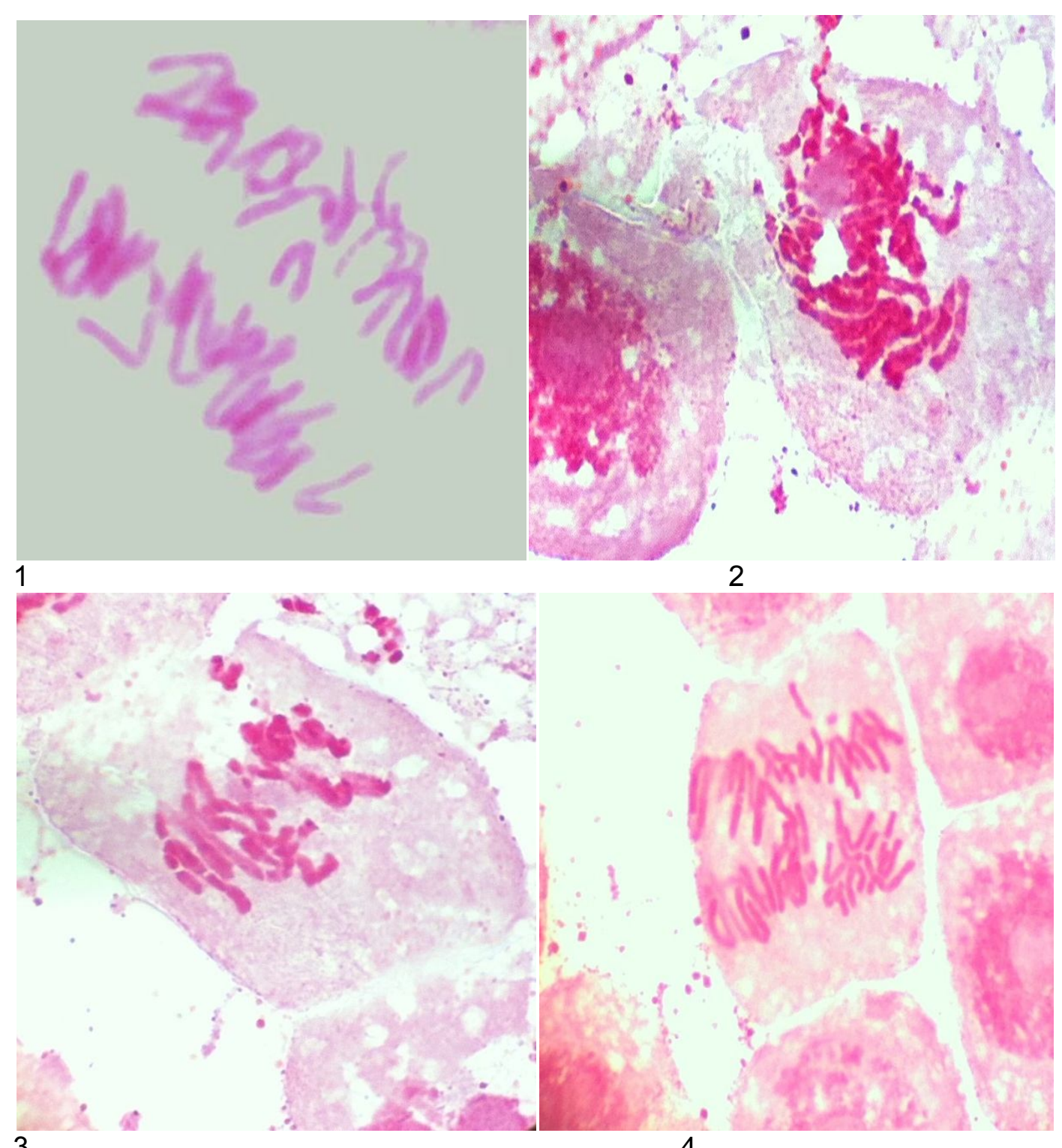

$$
2
$$

3

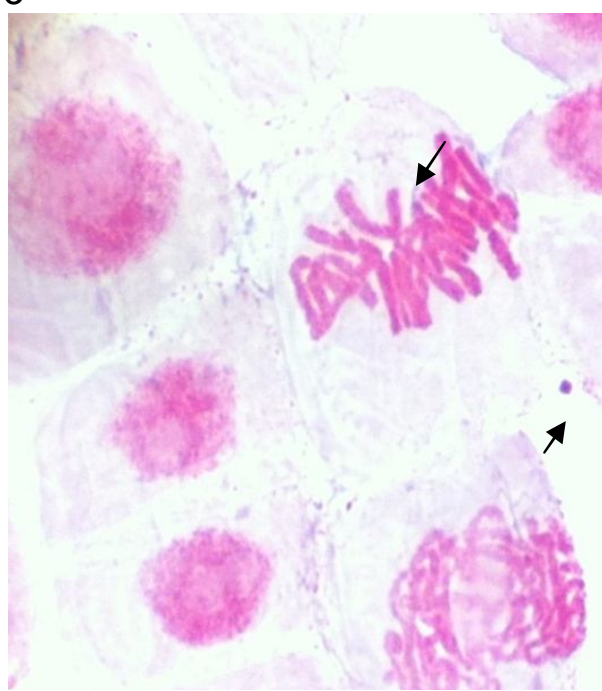

5

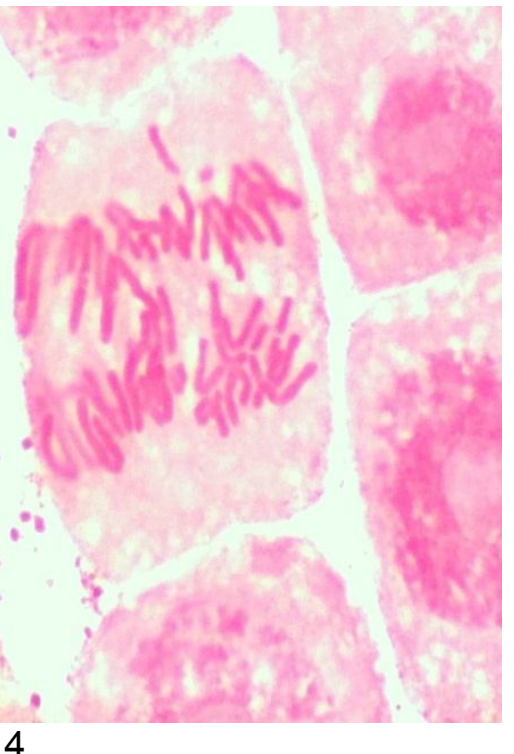

4

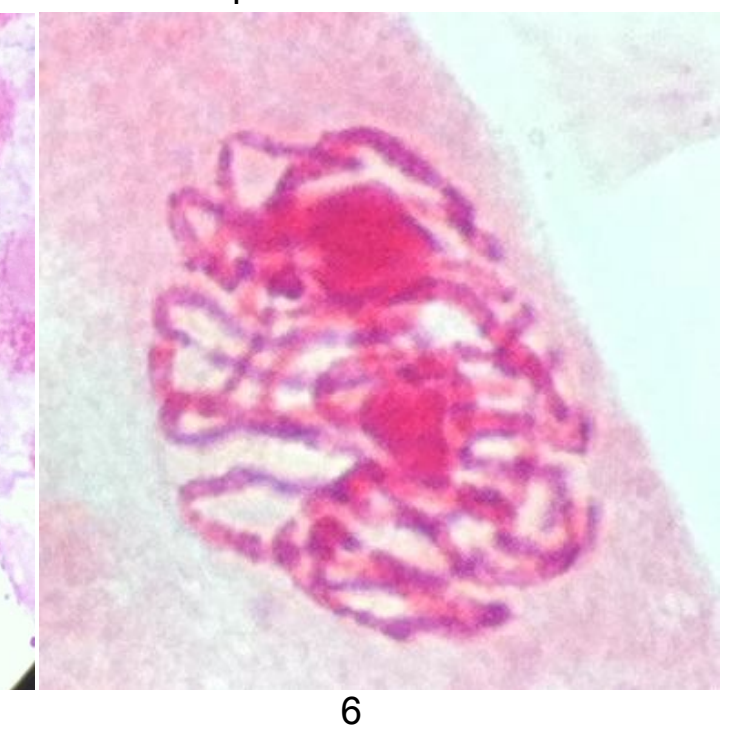



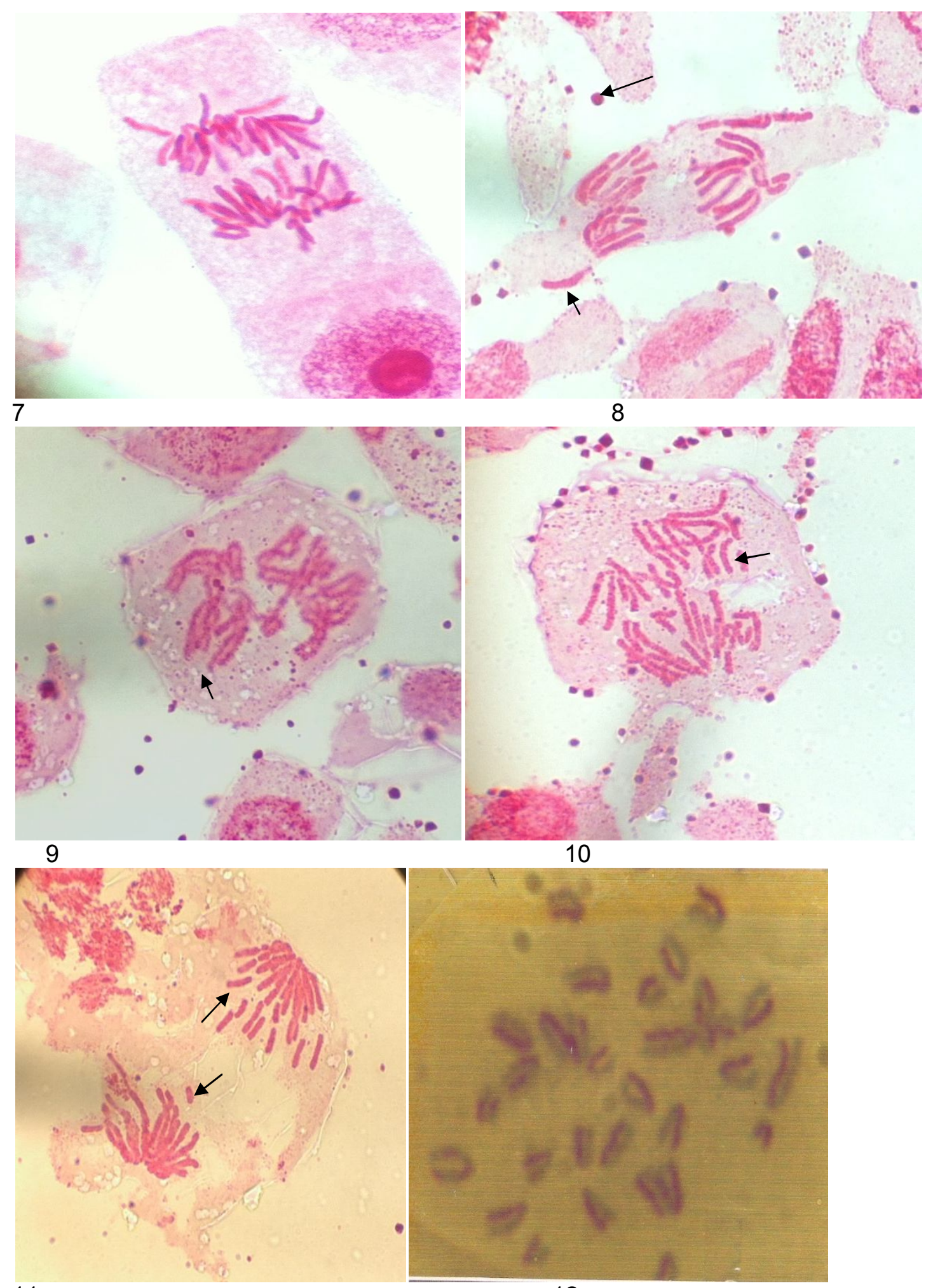

12 


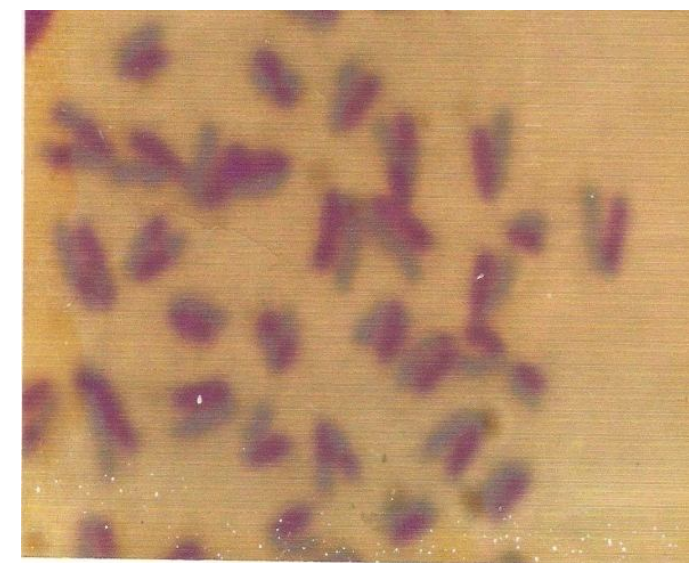

\begin{tabular}{|l|l|}
\hline Figure & Description \\
\hline 1 & Chromatid deletion A. cepa \\
\hline 2 & Fragments V. faba \\
\hline 3 & Fragments and Gap $\quad$ V. faba \\
\hline 4 & $\begin{array}{l}\text { Fragments, Chromatid deletion and Gap A. } \\
\text { cepa }\end{array}$ \\
\hline 5 & Chromatid deletion \\
\hline 6 & Binucleolei , V. faba \\
\hline 7 & Normal chromosomes $\quad$ A.cepa \\
\hline 8 & Chromatid deletion $\quad$ A.cepa \\
\hline 9 & Chromatid deletion, $\quad$ V.faba \\
\hline 10 & Chromatid deletion $\quad$ A.cepa \\
\hline 11 & Fragments and Chromosome deletion, A.cepa \\
\hline 12 & Sister chromatid exchange, Burger treatment \\
\hline 13 & Sister chromatid exchange, Corn chips \\
\hline
\end{tabular}

\section{DISCUSSION}

This work aims at disclosing the possible genotoxic effect (clastogenic and mutagenic as well) induced by some fast foods The recognition that diet may be one of the most important factors explaining international variation in cancer came when it was appreciated that for many cancers, diet seemed to be the most rational explanation (Higginson and Muir, 1979), coupled with studies at the macro-population level which indicated substantial correlations between incidence or mortality of cancer at various sites and various estimates of population consumption of dietary items (Armstrong and Doll, 1975; Knox, 1977). The explosion of interest that has followed, particulary in the past ten years, has gradually led to a recognition that many of the relationships are complex, involving not only factors that increase the risk of cancer, but also protective factors. Further, we do not appear to be dealing with simple expression of carcinogens and mutagens, rather diet seems to act on both the early and late stages of carcinogenesis. 
The associations with dietary factors and cancer incidence or mortality studied internationally, through strong, only point to the importance of dietary factors in etiology, they cannot prove causation. For this, it is necessary to conduct studies on diet in individuals, and then to confirm causation and measure to impact of preventive actions, conduct intervention studies in populations. For diet and nutrition, many studies on individuals have been conducted, but so far studies on populations have been reported. The studies on individuals are of two types, case-control and cohort. Case-control studies are based on the disease, looking back to the relevant exposures. There have been relatively few cohort studies, and most with information available currently were originally planned to concentrate on cardiovascular diseases. Case-control studies of diet and cancer have been more numerous, leading us to evaluate diet largely in relation to individual cancer sites. These vary from those in which diet seems to play a major role, such as stomach and colon and rectum, through those to which diet seems to make a major contribution, such as breast, prostate and many of the hormonally associated cancers, to those with important, well-recognized non-dietary causative factors to which dieter factors contribute to or modify risk, such as lung, bladder and other smoking and/of alcohol- associated cancers (Miller, 1986).

However, anticarcinogens have been reported in other foods and are postulated to mitigate the potentially deleterious effect of the low levels of mutagens and carcinogens that are ingested daily (Ames, 1983; Wattenberg, 1983). In particular modulator-mediated inhibition of carcinogenesis is of importance given that carcinogenic poly-nuclear arenes and heterocyclic amines are found in some cooked foods. Since case-control epidemimiologic investigations of the possible association of beef an other meats with colorectal and breast cancers are at present unclear (Doll and Peto, 1981), one might speculate that the modulator reported herein may under some circumstance act to moderate the effects of low levels of carcinogens that may be present, resulting in epidemiologic finding that are equivocal. Silalahi (2002).

The present investigation showed that the tested fast foods were proven to be clastogenic agents, since they were capable to interfere with spindle fibers, and C-metaphases were observed, giving a strong evidence that the water-soluble fraction of potato and corn chips as well as of Burger contained contaminants capable to interact with chromosomes arid spindle fibers as well. However they have mutagenic activity as sister chromatid exchanges revealed obtained since positive frequencies of SCEs were observed.

In conclusion clastogenic and mutagenic effect of these fast foods, under study, had been formed.

This positive clastogenic activity of water-soluble fraction of the tested foods may be caused by acrylamide or by heterocyclic amine ElSebeay (1999) and / or other contaminants. However, this question was not answered at the level of this work. 


\section{REFERENCES:}

Abdel GA, Hafez S (1995). GC- MS analysis and antimicrobial activity of volatile oil of Pituranthos tortuosus.. Q. Univ. Sci. J., 15(1): 23-36.

Al-Ayoubi, D. (1998). Piroxicam induced clastogenic effect in Vicia faba genome. J. Advances in Agric. Res. Alex. Univ; 3:100-120.

Albertini, R. J., Anderson, D., Douglas G.R. (2000). IPCS Guidelines for the Monitoring of Genotoxic Effects of Carcinogenes in Humans. Mutat. Res463:111-172.

Amara A, El-Masry M, Bogdady H (2008). Plant crude extracts could be the solution: Extracts showing in vivo antitumorigenic activity. J. Pharm. Sci., 21(2): 159-171.

Ames BN (1993). Dietary carcinogens and anticarcinogens. Science 3: 24155-24215.

Ames BN, Gold LS (1992). Animal cancer tests and cancer prevention. J. Natl. Cancer Inst. Monogr., 12: 125-132.

Armstrong B, and R. Doll (1975). Environmental factors and cancer incidence and mortality in different countries, with special reference to dietary practices. Int J. Cancer $15: 617-631$.

Badr, A. (1993) Cytogenetic activities of atrazine herbicide in root-tips of Allium cepa and Vicia faba. Mutat. Res., 117: 173-182.

Badr, E.A., M.A. Seehy, and H.G. Shalabi (1983). Sister chromatid exchange detection in plants: A genetic assay of primary DNA damage induced by pesticides. Internat. Cong. Genetics, New Delhi, Abst. Part I : 271.

Darlington, C.D., and L.F. La Cour (1962). The handling of chromosomes. Ed. Georg Allen \& Unwin Ltd., London.

Doll R, and R Peto (1981). The causes of cancer : Quantitative estimates of avoidale risks of cancer in the United States today. JNCl $66: 1191$ 1308.

El-Sebeay, A. (1999). Nutrition education program built on results of studying, buying, and nutritional practices of fast and snack foods among students in alexandria city and genetic effect on experimental animals. PhD. Fac. Agric. Alex. Univ.

Eriksson C (1981). Maillard reactions in food. Prog Food Nutr Sci 5 : 429466.

Higginson J. and CS Muir (1979). Environmental carcinogenesis : misconceptions and limitations to cancer control. J Natl cancer Inst 63 : 1291-1298.

Knox E.G. (1977). Foods and diseases. Br J Soc prev Med $31: 71-80$.

Knudsen, I.B.(1986). Genetic Toxicology of the diet. Proc. Sat. symp. 4th Internat. Environ. Mutagens.

Li J, Li Q, Feng T, Li K (2008). Aqueous extract of Solanum nigrum inhibit growth of cervical carcinoma (U14) via modulating immune response of tumor bearing mice and inducing apoptosis of tumor cells, 79(7): 548556.

Miller, A. B. (1986). Diet and nutrition in the context of cancer epidemiology. In : Genetic Toxicology of the Diet [Ed. Ib Knudsen] Alan R. Liss Inc. 
New York.

Perry, P. and Evans, H. J. (1975). Cytological Detection of MutagenCarcinogen Exposure by Sister Chromatid Exchange. Nature 258:121125.

Seehy M.A., Moghazy, O.M., El-Okazy, A.M. and Sulyman M:M (2013). Effect of Mannan and B-Glucan as feed additive on genotoxicity and immunity of broilers J. Alex. Science exch. Vol. 34 (2) 164-169.

Seehy, M. A., H.G. Shalabi, N. Shaker and Effat Badr. (1983). In vivo induction of sister chromatid exchanges in mice by cypermethrin. Proc Int. Conf. Env. Haz. Agrochem., Vol.1: 659 - 679.

Silalahi J (2002). Anticancer and health protective properties of citrus fruit Components Asia Pacific J. Clin. Nutr., 11(1): 79-84.

Wattenberg LW (1983). Inhibition of neoplasia by minor dietary constituent. Cancer Res. (Suppl.) 43: 2448s-2453s.

$$
\text { الملخص العربي }
$$

الأثر التكسيري والطفري والمستحدث بواسطة بعض الاغذية السريعة

أميرة خطاب

معهد الدراسات العليا والبحوث- جامعة الاسكندرية - جمهورية مصر العربية وكلية التربية جامعة المجمعة المملكة العربية السعودية

أجرى هذا البحث بغرض الكثف عن قدرة بعض الاغذية السربعة في احداث تكسير

للكروموسومات أو حدوث طفرات. ولتحقيق هذا الغرض تم اختيار ثثلاث اغذية سربعة وتم اختيار الفئران المعملية البيضاء للكثف عن قدرة هذه الاغذية في احداث تكسير للكروموسومات وتم توظيف خلايا الدم البيضاء لعمل اختبار تبادل الكروموتيدات الثقيقة للكثف عن القدرة الطفرية لهذه الاغذية.

وأظهرت النتائج أن هذه الاغذية لها القدرة على تكسير الكروموسومات والتداخل مع خيوط المغزل ولها قدرة طفرة كما أوضحت النتائج المتحصل عليها من نتائج اختبار نبادل الكروموتيدات الثقيقة ان لها قدرة طفرية. 
